\title{
Simultaneous Convexity Meningioma and Prolactinoma
}

Sir,

The coexistence of simultaneous pituitary adenoma and intracranial tumor is frequent and is widely identified in patients who have had radiotherapy as treatment for adenoma, as well as patients with neurocutaneous syndromes, such as Neurofibromatosis, and patients with breast cancer and meningioma apparently due to hormonal influence. ${ }^{[1-3]}$ However, the presence of pituitary adenoma simultaneous with intracranial tumor is very rare, especially as an adjacent lesion..$^{[1-5]}$

A 57-year-old right-handed dominant man, with Type 2 diabetes, presented to the emergency unit after experiencing a generalized tonic-clonic seizure; he mentioned that he has had 3 previous episodes of seizures in past month, all of them involving disconnection with the environment, perioral cyanosis, urinary incontinence, and decreasing visual acuity. On neurological examination, the patient has motor aphasia and right hemiparesis. Magnetic resonance image of the brain reported a lesion in the sellar region and a tumor mass suggestive of a convexity left frontal meningioma [Figure 1a-d].

It was decided for surgical treatment, with resection of the left frontal convexity meningioma (Simpson I). An extra-axial dura mater adherent, regularly vascularized, solid neoplasm with local bone involvement, exerting significant mass effect over cerebral parenchyma was found. The lesion was completely removed, along with the involved dura mater portion, a $1 \mathrm{~cm}$ dural margin and the affected bone portion. A duroplasty with pericranium was then performed, and medical treatment with cabergoline was started by the endocrinology team for a prolactin-producing pituitary macroadenoma.
Postsurgery follow-ups with total seizure control and partial improvement of motor and language impairment were pathology results: mixed and metaplastic meningioma. The patient was discharged home 7 days after the procedure for outpatient follow-up.

There were few case reports of pituitary adenomas coincident with tumors of glial origin, such as medulloblastomas, schwannomas, meningiomas, and some of them even with contiguous lesions..$^{[1,4]}$ Pituitary adenomas represent $10 \%$ of all intracranial neoplasms, and meningiomas $15 \%$, nevertheless, it is very uncommon to find a synchronic growth of these two lesions. ${ }^{[5]}$ The most common concurrence of simultaneous tumors is of glioma with meningioma, followed by pituitary adenoma with meningioma, and neurinoma with meningioma. ${ }^{[4]}$ The synchronic appearance of pituitary adenoma and meningioma has several theories; Furtado et al. suggest an undetermined genetic association among simultaneous intracranial tumors, and describe certain abnormalities in chromosomes 14 and 22, which are shared between pituitary adenomas and meningiomas. ${ }^{[3,4]}$ High levels of prolactin receptors or insulin-like growth factors 1 that stimulate mesodermic and ectodermic cell growth, that leads to tumor growth, may be present in functional adenomas. ${ }^{[4]}$ Ubea et al. have described that pituitary adenomas express fibroblast growth factor 1 and 2, along with multiple endocrine neoplasm, meningiomas and high circulating levels. Cannavò et al. ${ }^{[1]}$ found no relation between simultaneous growth hormone-secreting adenoma with meningioma, and receptors for growth hormone and growth factors in meningiomas; forth is reason, the authors believe these are independent events. High-resolution imaging 

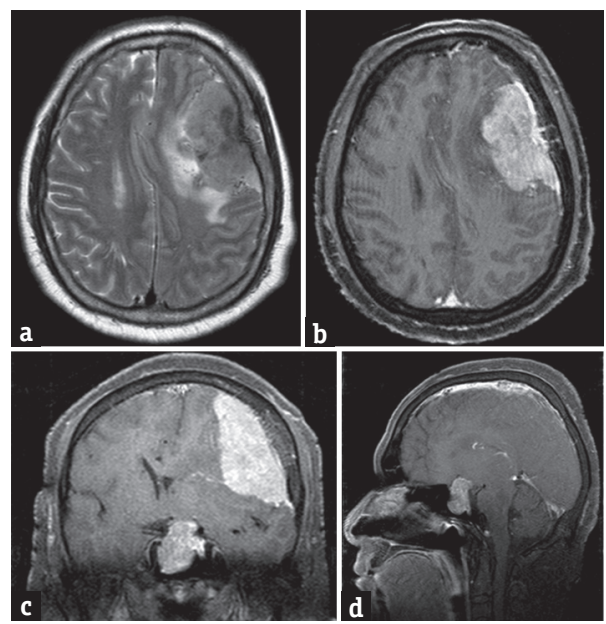

Figure 1: (a-d) Magnetic resonance imaging of brain showing two tumor lesions, the first compatible with convexity meningioma and the second with hypophyseal adenoma with supra sellar expansion of $2 \mathrm{~cm} \times 1.7 \mathrm{~cm}$

techniques can influence the fortuitous detection of coexistent intracranial tumors. ${ }^{[6]}$ The relationship between pituitary adenomas treated with radiation and asynchronous growth of a meningioma is deeply studied and well recognized, given that it is more frequent in these situations growth of sarcoma and glioma neoplasms. ${ }^{[2,3,5,6]}$ Functioning and nonfunctioning pituitary adenomas associated to meningiomas have approximately the same prevalence, from which growth hormone-secreting and prolactinoma are more frequent. The predominant histological types of meningioma are meningoendothelial and transitional. ${ }^{[1,3]}$

Finally, surgical resection is indicated for the meningioma, and the management of the pituitary adenoma is depended on tumor size and hormonal type. The multidisciplinary management by neurosurgery and endocrinology team will be fundamental for the successful resolution of these pathologies.

\section{Declaration of patient consent}

The authors certify that they have obtained all appropriate patient consent forms. In the form, the patient has given their consent for their images and other clinical information to be reported in the journal. The patient understands that name and initials will not be published and due efforts will be made to conceal identity, but anonymity cannot be guaranteed.

\section{Financial support and sponsorship}

Nil.

\section{Conflicts of interest}

There are no conflicts of interest.
Vladimir Figueroa-Angel, Willem Guillermo Calderon-Miranda, Nidia Escobar-Hernandez, Andrei F. Joaquim ${ }^{1}$, Luis Rafael Moscote-Salazar ${ }^{2}$ Emericella Renna Roldan-Medellin', Estefania Casasa Velez ${ }^{3}$ Maria del Rocio Estrada-Hernandez Department of Radiology, Hospital General Gea Gonzalez, Mexico City, Mexico, ${ }^{1}$ Department of Neurology, Division of Neurosurgery, State University of Campinas, São Paulo, Brazil, ${ }^{2}$ Department of Neurosurgery,

University of Cartagena, Cartagena, Colombia ${ }^{3}$ Medicine, Hospital General Gea Gonzalez, Mexico City, Mexico

Address for correspondence: Dr. Luis Rafael Moscote-Salazar, University of Cartagena, Cartagena De Indias, Colombia. E-mail: mineurocirujano@aol.com

\section{REFERENCES}

1. Cannavò S, Curtò L, Fazio R, Paterniti S, Blandino A, Marafioti $\mathrm{T}$, et al. Coexistence of growth hormone-secreting pituitary adenoma and intracranial meningioma: A case report and review of the literature. J Endocrinol Invest 1993;16:703-8.

2. Partington MD, Davis DH. Radiation-induced meningioma after treatment for pituitary adenoma: Case report and literature review. Neurosurgery 1990;26:329-31.

3. Abs R, Parizel PM, Willems PJ, Van de Kelft E, Verlooy J, Mahler C, et al. The association of meningioma and pituitary adenoma: Report of seven cases and review of the literature. Eur Neurol 1993;33:416-22

4. Furtado SV, Venkatesh PK, Ghosal N, Hegde AS. Coexisting intracranial tumors with pituitary adenomas: Genetic association or coincidence? J Cancer Res Ther 2010;6:221-3.

5. Canda T, Sengiz S, Canda MS, Acar UD, Erbayraktar RS, Yilmaz HS, et al. Histochemical and immunohistochemical features of a case showing association of meningioma and prolactinoma containing amyloid. Brain Tumor Pathol 2002;19:1-3.

6. Mathuriya SN, Vasishta RK, Dash RJ, Kak VK. Pituitary adenoma and parasagittal meningioma: An unusual association. Neurol India 2000;48:72-4

This is an open access article distributed under the terms of the Creative Common Attribution-NonCommercial-ShareAlike 3.0 License, which allows others to remix, tweak, and build upon the work non-commercially, as long as the author is credited and the new creations are licensed under the identical terms.

\begin{tabular}{|c|c|}
\hline \multicolumn{2}{|c|}{ Access this article online } \\
\hline $\begin{array}{c}\text { Quick Response Code: } \\
\text { (1) }\end{array}$ & $\begin{array}{l}\text { Website: } \\
\text { www.ruralneuropractice.com }\end{array}$ \\
\hline 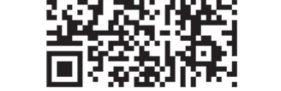 & $\begin{array}{l}\text { DOI: } \\
\text { 10.4103/jnrp.jnrp_374_17 }\end{array}$ \\
\hline
\end{tabular}

How to cite this article: Figueroa-Angel V, Calderon-Miranda WG, Escobar-Hernandez N, Joaquim AF, Moscote-Salazar LR, Roldan-Medellin ER, et al. Simultaneous convexity meningioma and Prolactinoma.J Neurosci Rural Pract 2017;8:684-5.

C 2017 Journal of Neurosciences in Rural Practice | Published by Wolters Kluwer - Medknow 